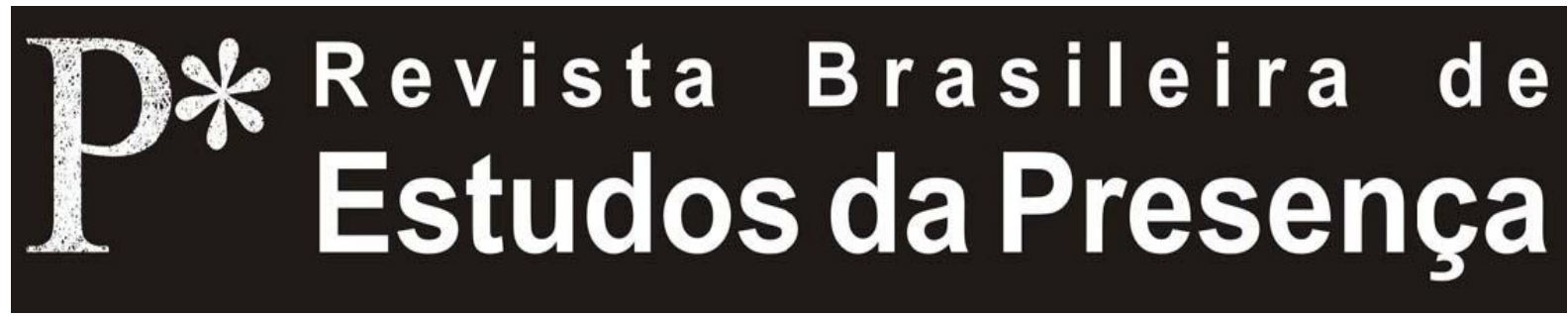

DOI - http://dx.doi.org/10.1590/2237-266041986

ISSN 2237-2660

\title{
0 Trabalho do Ator e a Arte de Ficcionar a Si Mesmo
}

\author{
Celina Nunes de Alcântara \\ Universidade Federal do Rio Grande do Sul - UFRGS, Porto Alegre/RS, Brasil
}

RESUMO - O Trabalho do Ator e a Arte de Ficcionar a Si Mesmo - Este artigo trata sobre o trabalho do ator como possibilidade de criação, de invenção de si. Relaciona-se essa ideia a modos de ficcionar a si mesmo, ou seja, a maneiras de pensar o trabalho do ator sobre si como uma formação possível de projetar-se para além da criação artística, chegando a reverberar no prosaico da vida cotidiana. Para sustentar tal discussão, foram abordados os conceitos de ética, verdade e cuidado de si, além de outros, conforme tratados na obra de Michel Foucault. Além disso, do campo teatral tomam-se as noçóes de segunda natureza e corpo fictício, problematizadas a partir de Constantin Stanislavski, Franco Ruffini, Eugenio Barba e Nicola Savarese.

Palavras-chave: Ator. Criação. Ficção. Transformação. Formação.

ABSTRACT - The Actor's Work and the Art of Fictionalising Oneself - This article discusses the actor's work as a possibility of creation and invention of the self. This concept is related to ways of fictionalising oneself, that is, ways to think an actor's work on themselves as a possible way to project the self beyond artistic creation, even coming to reverberate in ordinary daily life. To support this discussion, we addressed the concepts of ethics, truth, and care of the self, as they are discussed in the work of Michel Foucault and others. Furthermore, we drew from theatre notions of second nature and fictitious body, problematised based on the ideas of Constantin Stanislavski, Franco Ruffini, Eugenio Barba, and Nicola Savarese.

Keywords: Actor. Creation. Fiction. Transformation. Training.

RÉSUMÉ - Le Travail de l'Acteur et l'Art de la Fiction de Soi - Cet article envisage le travail de l'acteur comme une possibilité de création, d'invention de soi. Cette idée est mise en rapport avec des modes de fiction de soi-même, c'est-à-dire, des manières d'envisager le travail de l'acteur sur soi comme une formation qui tend à dépasser la création artistique, pouvant réverbérer dans le prosaïque de la vie quotidienne. Cette réflexion s'appuie sur les concepts d'éthique, de vérité et de soin de soi, tels qu'ils ont été traités dans l'œuvre de Michel Foucault; entre autres. Du champ théâtral sont empruntées les notions de seconde nature et de corps fictif, problématisées à partir de Constantin Stanislavski, Franco Ruffini, Eugneio Barba et Nicola Savarese.

Mots-clés: Acteur. Création. Fiction. Transformation. Formation. 
Neste artigo, gostaria de discutir uma questão que já há algum tempo tem sido parte das minhas inquietaçóes como atriz e professora de teatro. Trata-se de pensar o trabalho que o artista ator faz sobre si mesmo para o exercício da linguagem teatral como possibilidade de criação, de invenção, de transformação de si mesmo para além do acontecimento teatral, mas, ainda assim, a ele conectado, criando algo que se aproxime de uma ficção de si mesmo.

Falar em ficção de si, relacionada à experiência com a criação teatral, implica, sobretudo, a meu ver, falar em transformação. Mas a que tipo de transformação aludo quando a relaciono a uma ideia de ficção na experiência teatral?

Tenho pensado sobre minha prática como artista e docente e, em especial, sobre o modo de forjá-la em mim e naqueles com os quais me dedico à difícil tarefa de uma formaçáo em teatro. É na condiçáo de professora e atriz que construo os argumentos que gostaria de compartilhar aqui. Digo isso para lembrar que a prática teatral é, antes de tudo, uma experiência, uma experiência de si, um si em experiência. E o é, como atesta Chauí (2002), pois nos inicia naquilo que não somos. Pergunto-me se não seria justamente essa iniciação ao que não somos o sustentáculo para aquilo que talvez venhamos a ser. Eis a experiência incitando a transformação que, por sua vez, é também experiência.

Ora, o trabalho sobre si não se configura para nós, atrizes e atores, homens e mulheres de teatro, senáo na relação com o outro da cena. Assim, a transformação da qual falo não se assemelha àquela que emana da fé ligada às esferas místicas ou religiosas.

A transformação que a prática teatral pode, talvez, provocar em alguns indivíduos, sob determinadas circunstâncias, tem seu modo de constituir-se, de configurar-se como prática; ela incita um modo de agir sobre o mundo, de estabelecer uma relação com a alteridade. Essa transformação extrapola a individualidade do ator porque perpassa a atuação de um sujeito criador, e náo somente de um indivíduo artista. Imagino que a transformaçáo possa ser pensada a partir da própria palavra por três aspectos que a constituem: passagem (trans), forma (form) e ação (ação).

O primeiro aspecto alude a um certo caráter movente do ato de transformar (ou transformar-se): pode-se pensar aqui na passagem de um estado a outro, de uma situação a outra, de um acontecimento a outro, de um espaço a outro. Trata-se da ideia que se liga à noçấo 
de viagem, de passagem, seja esta temporal ou espacial. Ligada a essa noção, a ideia de transformação lembra também a forma como algo se faz, se refaz, se desfaz, sendo capaz de tomar outra feição, outro caráter. Ou como uma metamorfose, uma transmutação, característica daquilo ou daquele que é capaz de mudar de forma ou de aparência. Na mesma direção, a palavra transformaçáo se liga à ação de mudar, ao próprio fenômeno da mudança. Nesse caso, diz respeito a pensá-la como a ação de transmutar a forma, como o movimento cambiante de adquirir outra forma, de constituir-se no diferente de si pelo movimento.

Com efeito, o teatro conjumina todos esses aspectos da palavra transformaçáo, pois ele, na forma como nos foi dado a conhecer no mundo euro-americano, é uma linguagem artística que, em alguma medida, compromete - ou transforma - necessariamente o eu do sujeito que o pratica. Basta refletirmos sobre duas questóes fundantes do trabalho do ator: uma atávica e outra de caráter histórico.

A obra teatral se faz no artista, ou seja, o ator é, ao mesmo tempo, criador e objeto. Por outro lado, mas não em oposição a essa primeira questáo, a gênese do teatro euro-americano está relacionada a um ritual em honra a um deus capaz de transformar-se em outros seres. Diònisus é um deus capaz de entrar em transe e passar o seu delírio aos participantes do ritual. No ritual dionisíaco, os participantes saem de si e mergulham no deus. A prática de representar em outro que não a si mesmo tem origem, assim, no delírio dionisíaco (Carlson, 1997). É a partir daí, também, que se origina a ideia do ator como alguém capaz de representar outro que não a ele mesmo.

Muito embora no século XX tenhamos presenciado muitas transformaçóes nos modos de fazer e pensar o teatro, sobretudo no âmbito do trabalho do ator (e, em especial, na forma como este último se relaciona com a própria criação), esta acepção que identifica o ator como alguém que representa ou re-apresenta um ser (personagem) diferente de si, ao ficcioná-lo em seu corpo, está profundamente arraigada nos nossos modos de ver, pensar e formar o ator.

Náo obstante, a partir das transformaçóes no campo do teatro que sucederam desde o início do século passado, foi exigida do ator uma relaçáo com a própria criação que ultrapassasse os limites da cena, no sentido mesmo de uma relação direta entre transformação pessoal e profundidade no ato de criação. 
Essa intuição já estava claramente plasmada nas ideias de Stanislavski ${ }^{1}$ no início do século XX. Para ele o trabalho sobre si mesmo constituiria a instância fundamental na preparação do ator. Na visão de Ruffini (2007),

[...] além de construir programaticamente um sistema para o trabalho do ator, o pensamento de Stanislavski construiu objetivamente uma técnica para o trabalho sobre si mesmo. Fechar-se a esta projeção ulterior, ou não ser capaz de percebê-la, equivale a banalizar o pensamento de Stanislavski. E matar o valor do teatro (Ruffini, 2007, p. 4, tradução nossa).

Não é difícil perceber que, na história da pedagogia do ator durante o século XX, os mais diversos diretores-pedagogos pensaram $\mathrm{o}$ ator não apenas como um executor, como um intérprete das ideias do dramaturgo, mas como um criador, como um artista que se faz, que faz a si mesmo na sua poiética teatral, inclusive sendo intérprete do dramaturgo (Icle, 2010).

Não podemos nos esquecer de considerar as contribuiçóes de Stanislavski, Meyerhold, Copeau, Brecht, Grotowski, Barba (para citar alguns) como fundamentais para pensarmos o modo pelo qual o trabalho do ator sobre si mesmo foi se constituindo como ferramenta fundamental no campo teatral. Por isso mesmo, cabe lembrar a centralidade que tais diretores deram à constituição de si mesmo como ser ético, conduta que era demandada dos atores.

Parece evidente que, para esses diretores, o trabalho do ator sobre si constituía uma instância eficaz de tornar-se sujeito na/da sua prática. Cada um, na sua perspectiva de trabalho, fez proposiçóes que demandavam do ator engajamento e transformaçáo em um nível que podemos chamar de psicofísico, ou seja, como um corpo-mente orgânico (Ruffini apud Barba; Savarese, 1995). Tratava-se, ao fim e ao cabo, de uma relaçáo com o trabalho que deveria (ou, ao menos, poderia) extrapolar a prática teatral da cena.

\section{Constituir a Si Mesmo na Experiência Teatral}

Ao debruçar-me sobre o conceito de experiência, algumas elaboraçóes teóricas me pareceram bastante potentes para pensar a experiência teatral. Destaco o modo como Marilena Chauí constrói seu pensamento em torno do conceito de experiência amparada em Merleau-Ponty, e que me calou profundamente, na medida em que 
ela parece descrever a potência do acontecimento teatral (como cena e criação), ainda que náo esteja se referindo a ele.

É assim quando a autora menciona: "[...] a emergência de um ser que se ouve falando e se duplica porque se diz a si mesmo, vai sendo à medida que se vai dizendo, como aquele que, ao despertar, diz: dormi" (Chauí, 2002, p. 17-18). Ou ao referir-se à experiência do pensamento e da fala, quando aponta a ideia de uma racionalidade alargada que pudesse "[...] compreender aquilo que em nós e nos outros precede e excede a razão" (2002, p. 7). Ou ainda aquilo que ela descreve como uma geração inesgotável de seres, ideias, acontecimentos e situaçóes, possíveis de se abrirem para a experiência não como objetos do pensamento, mas como experiência de pensar.

Para pensar sobre a experiência - mormente sob a égide do acontecimento teatral -, talvez precisemos primeiro "[...] avaliar o que o pensamento roubara de si mesmo ao pagar tributo à soberania da consciência e das representaçóes" (Chauí, 2002, p. 6) o que é possível pensar para além de um atrelamento a um sujeito/indivíduo uno, consciente, soberano, detentor da experiência e preso a um pensamento dual. Talvez precisemos nos voltar para "[...] o mistério que faz o silêncio sustentar a palavra, o invisível sustentar a visão e o excesso das significaçóes sustentar o conceito" (2002, p. 12), para algo que náo está em uma racionalidade, num sentido positivo, num modelo a ser decodificado e tornado exemplo, mas que é, ainda assim, encarnado e vivo. E nos tornarmos, quiçá, "[...] um ser que é aquilo de que fala, que vai sendo à medida que vai falando" (2002, p. 15).

Se aquiescermos à ideia de Chauí (2002) - segundo a qual, por força de uma experiência, somos lançados para aquilo que não somos -, é preciso também não perder de vista que uma iniciação ao que náo somos, a partir desse modo de elaborar o pensamento, náo caminha em consonância com um sujeito que age, que toma decisóes, consciente, senhor e assenhorado dos acontecimentos e também da experiência. Ela parece envolver um movimento que pode principiar desde um ímpeto que impele a um determinado lugar, a um ser, a uma ação, até aquilo que de transformação emerja nesse encontro. No entanto, não há garantias nisso. Não há medidas. A experiência se erige no espaço do imponderado, do náo limitado, do incerto, do que não é dizível ou visível, mas, ao mesmo tempo, sendo.

$\mathrm{Na}$ esteira desses argumentos, ocorre-me pensar que, na relação de um artista ator, consigo mesmo e com os outros, possa erigir-se, ao 
mesmo tempo, um modo complexo e tangível de formulação de uma experiência. Não que esse artista seja mais ou menos sensível, mais ou menos criativo, ou mesmo que sua ação seja mais importante do que a de outros artistas ou outros seres humanos. Trata-se, sim, da prática artística assentada numa construção que envolve uma edificaçáo de si na relação com os outros e que, justamente nessa condição, parece capaz de provocar um secreto mal-estar, um jeito diverso de olhar para si e para os outros. Prática esta que pode extrapolar uma individualidade, um tempo, um espaço, ainda que conectada a eles. Talvez como uma personagem posta em cena e capaz de capturar aquele que a especta, quase à revelia do próprio espectador.

Desse modo, a experiência seria "[...] um estar fora de si sem sair de si, pois para realizá-la, nosso corpo precisa ser uma coisa entre as coisas" (Chauí, 2002, p. 127). Ao mesmo tempo, precisamos nos manter atentos para náo confundir experiência com a noção de comportamento (corporal) e de consciência (perceptiva). Devemos pensá-la naquilo que ela abre para o que náo somos nós, ou seja, para a

[...] excentricidade muito mais do que [para o] descentramento, a experiência 'não é um modo de presença a si, é o meio que me é dado para estar ausente de mim mesmo, de assistir de dentro a fissão do Ser fechando-me sobre mim somente quando ela chega ao fim'. Isto é, rigorosamente: nunca (Chauí, 2002, p. 138).

Ora, ao abrir-se para o que não somos nós, a experiência, conforme Chauí (2002), não pode ser considerada como algo do âmbito de nosso comportamento individual, tampouco como um acontecimento para nós. A experiência, segundo a filósofa,

[...] abre-se para o que em nós se vê quando vemos, em nós se fala quando falamos, em nós se pensa quando pensamos. Não regressa a um "antes" de nós, pois neste caso regressaria a Deus; fissão no Ser, abre-se para origem, para o que não é começo em si, antecedente. $\mathrm{O}$ originário é o que se institui na junção de um passado e de um porvir: sua hora é agora. É o que se institui na junção de um fora e de um dentro: seu lugar é aqui (Chauí, 2002, p. 139).

É nesse lugar que experiência e transformação se mesclam, é sob o signo desse imponderado que visualizo a transformação que pode emanar do teatro, transformação esta que teria seu lugar num eu e não num si. Mas como circunscrever essa dimensão que estamos nomeando de $s i$, bem como a sua relação com uma possível transformação através da prática teatral? 
$\mathrm{Na}$ primeira vez que tomei contato com os escritos de Michel Foucault em torno da formulação de si a partir da ascética dos gregos clássicos e dos primeiros séculos da era cristã - descrita no livro $A$ hermenêutica do sujeito (2004) - logo me veio à mente a formaçáo teatral e a necessária transformaçáo pela qual um ator passa para dar conta do acontecimento teatral. No entanto, antes que adentremos a seara dos mal-entendidos, adianto não estar afirmando que toda formação teatral constitui uma espécie de ascética e, menos ainda, que os atores fazem uma experiência semelhante à ascética clássica descrita por Foucault.

Ocorre que qualquer um que tenha passado por algum tipo de formação em teatro no campo do trabalho do ator pode atestar o quanto teve de transformar seu corpo, voz, lógica de movimentos, qualidade de atenção, capacidade de jogo, entre tantas outras mudanças, para conseguir elaborar uma criaçáo como ator, para atuar ou representar ${ }^{2}$. Trata-se de um conhecimento instrumental necessário para constituir e para constituir-se no universo da linguagem teatral. Para criar uma personagem, improvisar açóes, elaborar uma cena, é preciso uma instrumentalização do corpo e do pensamento, que tornam possível a experimentação dessa linguagem.

Não se pode perder de vista que tal instrumentalização implica muitos modos de constituir-se, modos táo diversos quanto as pessoas com as quais trabalhamos, a quem vimos em cena ou sobre cujos trabalhos soubemos por intermédio dos livros. As diferentes técnicas e os mais diversos exercícios que podem compor um dado universo teatral - ainda que estendamos esse universo apenas àquilo que nos é mais próximo, espacial e temporalmente - implicam que teremos um amplo espectro de atravessamentos, de influências. Como nos lembra a atriz Fernanda Montenegro ${ }^{3}$,

[...] esse testemunho da teatralidade humana vive além do tempo e além das fronteiras. A arte de representar não nasce e morre dentro dos limites de um país. Penso que todos nós nos influenciamos e, embora de comportamentos cênicos distintos, todos nós, atores, nos interdependemos (Montenegro, 1983, p. 2).

Ora, quando insisto em transformação a partir da aprendizagem da linguagem teatral, falo primeiro naquilo que incide sobre a fisiologia do corpo, aquilo que Burnier (2001) nomeia como "dimensáo física ou mecânica" que, segundo ele mesmo, não está separado de uma "dimensão interior" (2001, p. 19) que lhe é correspondente e 
inseparável. Essas dimensóes, quando conjuminadas formam uma única unidade. No entanto, essa unidade, para Burnier, nem sempre pode ser trabalhada como tal; por vezes, na formação de um ator, a unidade precisa ser colocada como o ponto de chegada, enquanto na caminhada, o trabalho pode incidir sobre uma ou outra dimensão de maneira a enfocá-las, ainda que momentaneamente, de forma separada.

Essa discussão se refere, sem dúvida, a uma das questôes consideradas basilares na experiência teatral - a necessidade da construção daquilo que alguns autores vão nomear como corpo fictício e outros como segunda natureza. Isso diz respeito ao modo pelo qual cada ator reinventa seu próprio corpo para tornar possível o exercício da linguagem teatral. Fundamentalmente, refere-se a uma transformação psicofísica, que torna possível a experiência da vida cênica.

A expressão "segunda natureza" (Ruffini, 2007), cunhada pelo diretor russo Constantin Stanislavski, diz respeito à forma pela qual o ator precisa reaprender as açóes que aprendeu no seu cotidiano, de modo a construir outra "natureza corporal". Esse ato, por sua vez, torna possível tanto a criação da obra teatral quanto uma transformação radical do sujeito que investe nessa formaçáo, posto que mobiliza diretamente o modo como aprendeu a utilizar seu corpo no cotidiano.

Assim, ao reportar a cena às leis da natureza, o objetivo do Sistema de Stanislavski era o de criar para o homem em cena a ideia de uma "segunda natureza". O autor fala em natureza porque o ator em condiçôes criativas não seria diferente do homem no meio "natural" (no cotidiano), mas acrescenta o adjetivo segunda porque, em cena, a natureza deve ser reconstruída através do trabalho sobre si mesmo (Ruffini, 2007, p. 39, tradução nossa). É possível dizer que a segunda natureza seria a capacidade de tornar real um evento fictício, visto que a reação a um evento (dito) real seria garantida pela primeira natureza (Ruffini, 2007, p. 39).

Para Stanislavski (2007), na assim denominada vida real, acredita-se em algo simplesmente por ser verdadeiro; porém, de acordo com seu modo de praticar o teatro, uma coisa torna-se verdadeira porque se crê nela. Eis aqui plasmado mais um traço sobre o fictício que interessa na composição desta discussão: a ficção como algo que se torna verdadeiro por força da crença que se tem nela.

Outra contribuição importante, sobretudo no campo da teorização teatral, é o modo como os autores Barba e Savarese (1995) 
pensaram e nomearam a criação que o ator faz sobre seu corpo, de modo a reinventá-lo na e para a prática teatral: corpo fictício. $\mathrm{Na}$ perspectiva desses autores, um corpo fictício é um corpo erigido a partir de princípios pré-expressivos. Para eles, tais princípios são noçôes que embasam a "vida do ator-bailarino" (1995, p. 18).

Entretanto, esses princípios não se relacionam somente com a fisiologia e a mecânica do corpo. Eles estáo baseados numa rede de ficçôes, mas ficçôes que lidam com forças físicas que movem o corpo. O que diferencia a busca de um corpo fictício de uma personalidade fictícia - mais coerente com a proposição stanislavskiana na fase inicial do seu trabalho - o fato de que a segunda possibilidade, que é também a mais tradicional na prática teatral euro-americana, está calcada em ficçóes que lidam com a psicologia, o comportamento e a história da personagem representada pelo ator.

Por outro lado, a busca por um corpo fictício é, antes de tudo, a necessidade de romper com as respostas automáticas do comportamento cotidiano. Para tanto, é necessário que o ator aprenda a fazer usos do seu corpo diferentemente do uso cotidiano; faz-se necessário constituir outra linguagem corporal que possibilite ao ator expressarse diferentemente da sua forma usual. Trata-se de uma transformaçáo, a um só tempo, física e mental, de aprender a agir de outra forma, agora numa perspectiva não cotidiana.

Esse universo corporal (não cotidiano, extracotidiano, fictício, cênico, como queiramos nomeá-lo) que o ator faz aflorar no seu corpo por meio do trabalho teatral não está apartado da sua dimensão cotidiana, prosaica; é ainda o mesmo corpo se fazendo e desfazendo - tal qual um ator ao entrar e sair de cena - por meio dessas múltiplas e, ao mesmo tempo, particulares dimensôes do seu próprio corpo. Assim, creio que as práticas, as técnicas e os exercícios ${ }^{4}$ praticados pelo ator apenas adquiram sentido de transformação se lhes possibilitarem uma mudança profunda a tal ponto de tornar possível, no ato da representação, um desnudamento, uma doação, uma exposição, um mergulho em si diante do público (Grotowski, 1987).

Um corpo capaz de produzir ficção é um corpo que se transformou, que traz em si as marcas psicofísicas de uma caminhada; ou seja, é um corpo que também se ficcionou: perceptível, identificável, mesmo que subjetivo.

O trabalho teatral náo incide sobre os corpos da mesma maneira, não provoca transformaçôes na mesma medida, ainda que as 
proposiçóes e os objetivos sejam os mesmos; tampouco opera algo que se assemelhe a um milagre. Isso ocorre porque as condiçóes de possibilidade para que o trabalho teatral aconteça são tão múltiplas, complexas e, ao mesmo tempo, táo difíceis de serem objetivadas quanto as próprias experiências teatrais. Por isso, quando me proponho a pensar nas transformaçóes possíveis a partir do exercício do teatro, de modo algum imagino algo objetável, mensurável ou mesmo passível de ser exemplificado pelo trabalho do ator. O que a prática teatral talvez possa trazer é imagem para o intangível, é tangência para o imponderado, espessura e forma para o que não pode ser delimitado, ainda que tenha lugar nos corpos.

Assim, como docente e como artista, ocorre-me aproveitar este exercício de pensamento para tentar apontar algo que seria basal para que o trabalho teatral seja instaurado, para que possa acontecer. Penso que talvez a capacidade de ser permeável, disponível, ao mesmo tempo, proponente e experimentador, com disposição para afetar e ser afetado - talvez isso seja a mola mestra, a chave, a senha, o portal que se abre para um campo de forças ${ }^{5}$. Ao mesmo tempo, a transformação somente é possível no exercício, na prática, naquilo que se relaciona com o agir.

Isso porque, para o ator, o que está posto em xeque é sempre o que ocorre no e com o corpo. Por isso, Artaud (1987), referindo-se ao trabalho do ator, fala em "atletismo afetivo" (Artaud, 1987, p. 162). Para ele, o ator é um atleta físico capaz de desenvolver uma "[...] musculatura afetiva que corresponda a localizaçôes físicas dos sentimentos" (1987, p. 162), criando, assim, um organismo afetivo análogo e paralelo ao físico, o qual funciona também como um duplo deste último, ainda que ambos não atuem no mesmo plano (Artaud, 1987).

Nesse sentido, da mesma forma que o atleta se vale de apoios físicos para impulsionar seus movimentos, o ator se apoia no corpo para lançar "uma impressão espasmódica" (Artaud, 1987, p. 162) ou uma ação psicofísica. Assim, as paixôes teriam os mesmos pontos físicos de sustentação de uma luta, de um salto, de uma corrida, porém com bases orgânicas análogas.

Isso remete diretamente à ideia de emoçáo. Etimologicamente, a palavra emoção vem da junção de em + motion, que significa em movimento (Burnier, 2001). É importante ressaltar que emoção não pode ser confundida com sentimento. Os sentimentos se referem a uma 
psiké, a uma psicologia. A emoção se refere a algo físico, muscular, radicado no corpo, a partir da capacidade que este tem de moverse, e náo de uma racionalidade ou de sentimentos centrados num eu que se expressa. A emoção nos reporta de volta à transformação, justamente naquilo que a primeira tem de movimento e, logo, de potencial de mudança.

\section{Constituir a Si Mesmo na Relação Teatral com a Verdade}

Ora, um $e u$ que se expressa, que quer se fazer notar, que precisa de reconhecimento do outro (principalmente do público) é algo que habita o âmbito do lugar comum na prática teatral, sobretudo com relação ao trabalho do ator. Circula no senso comum a ideia de que há uma relação indissociável entre ator e vaidade. Há quem afirme não ser possível tornar-se ator sem flertar, mesmo que de passagem, com a vaidade. Malgrado o caráter generalizante e lugar comum de tais afirmaçóes - já que elas aludem a algo (vaidade) que pode habitar os modos de ser e se relacionar de qualquer indivíduo, em qualquer tipo de relação (profissional ou não) -, o fato é que elas têm encontrado no ator e no seu trabalho um lugar privilegiado de expressão. Esse privilégio não está apartado de questóes inerentes a essa prática. Nesse sentido, talvez, a maior de todas elas seja mesmo a necessidade de exposição.

Seja pela natureza presencial do trabalho do ator, seja por um imaginário popular potencializado pelas diferentes mídias- que se referem ao ator como alguém que se possa e deva reconhecer, alguém que se distinguiria na multidão, mas também alguém cujo valor do trabalho está na glória conquistada. Trata-se aqui - já desde muito tempo - da capacidade de fazer-se lembrado, de ser reconhecido publicamente por força de suas açôes. Bem, mas qual a ligação entre esse preâmbulo introdutório e a temática da relação entre prática teatral e um modo de experimentar a verdade?

Estamos falando, aqui, daquilo que concerne à noçáo de transformação, atrelada à verdade de uma exposição. Isso, com efeito, constituiria um modo de articular a palavra poética, a narrativa e a celebração - próprias da prática teatral -, e a busca por uma experiência de si como forma de fugir do esquecimento, do silêncio e da morte, em prol de uma existência digna do louvor e da memória.

Toda essa discussão, a meu ver, tem uma relação íntima com o preceito clássico do conceito de cuidado de si (souci de soi), pensado 
por Michel Foucault. Trata-se da análise que o filósofo francês empreendeu a partir do exame de textos antigos, nos quais aparece, segundo ele, a sobreposição do preceito délfico gnôuthi seauton, "conhece-te a ti mesmo", sobre a noçáo de epiméleia heautoú, "cuidado de si" (Foucault, 2004, p. 5). Foucault afirma que, no seu surgimento, o preceito délfico gnôuthi seauton (conhece-te a ti mesmo) estava subordinado ao princípio do "cuida de ti mesmo" (Foucault, 2004, p. 7). Assim, foi em função do cuidado de si que se formulou a regra do "conhece-te a ti mesmo".

Historicamente, o preceito do cuidado de si configura-se como uma noçáo complexa e rica que perdurou amplamente e "[...] não cessou de constituir um princípio fundamental para caracterizar a atitude filosófica ao longo de quase toda a cultura grega, helenística e romana" (Foucault, 2004, p. 12), tendo se modificado radicalmente a partir "[...] de uma ética geral do não-egoísmo, seja sob uma forma cristã de renunciar a si, seja sob a forma "moderna" de uma obrigaçáo para com os outros" (Foucault, 2004, p. 17).

Para Foucault, essas regras - que se constituem como paradoxos - são algumas das razóes pelas quais o cuidado de si deixou de ser uma preocupação dos historiadores. Entretanto, ele atribui a sobreposição do conhecimento de si ao cuidado de si ao que ele denomina como uma razão bem mais essencial do que esses paradoxos da história da moral. Trata-se do "[...] problema da verdade e da história da verdade [...]" (Foucault, 2004, p. 18), problema este que vai se configurar de maneira muito diversa a partir daquilo que Foucault chama - embora alertando para a precariedade do termo - de "momento cartesiano".

Com efeito, o momento cartesiano estabeleceu uma requalificação do preceito clássico gnôuthi seauton, "conhece-te a ti mesmo", a partir de um procedimento que "[...] instaurou a evidência na origem, no ponto de partida do procedimento filosófico - a evidência tal como aparece, isto é, tal como se dá, tal como efetivamente se dá à consciência, sem qualquer dúvida possível" (Foucault, 2004, p. 18). Por força disso, o conhecimento de si passaria a se configurar como forma de consciência da indubitável existência do sujeito.

Ora, sobre cuidado de si de Foucault - bem como as ideias de alguns de seus comentadores - me chamou a atenção a possibilidade de relação entre os preceitos da antiguidade clássica apresentados pelo filósofo francês e as necessárias transformações psicofísicas para o ato teatral. Dou-me conta de que, se há algo de concreto a aprender 
com os antigos relidos por Foucault, é um certo silêncio organizado e atento, uma capacidade de escuta tanto técnica quanto ética, assim como uma técnica e uma ética da leitura e da escrita e exercícios de subjetivação de um discurso verdadeiro (Gros, 2004). Trata-se de um modo de se constituir diretamente relacionado a uma prática, ao domínio e ao conhecimento de uma técnica, a exercícios que agem na materialidade de um corpo. E talvez por isso seja possível o exercício da suspeita sobre nossas experiências teatrais contemporâneas, a partir das experiências dos antigos revistos por Foucault.

Em que medida nos aproximamos da ideia de experimentar a própria existência como autêntica obra de arte, como faziam os antigos relidos por Foucault? Ao mesmo tempo, se é possível pensar a prática teatral como possibilidade para essa edificaçáo, quais seriam os modos pelos quais ela se corporifica na experiência teatral? "Talvez sonhar", diz Hamlet (Shakespeare, 1995, p. 89). Talvez não tentar fazer, não querer ser, não querer dizer; buscar o silêncio, a pausa e a escuta, tantas vezes necessários na prática teatral, justamente para permitir que algo aconteça - deixar transparecer aquilo que fica obliterado pela necessidade de tudo mostrar, do fazer e dizer em excesso, tão comum em nossas vivências contemporâneas. Trata-se de abrir-se à possibilidade de que algo aconteça, sem exageros, na justa medida, como aconselha Hamlet ${ }^{6}$ aos atores na cena II do terceiro ato. Ele diz:

[...] ajustai o gesto à palavra, a palavra à ação; com esta observância especial, que não sobrepujeis a moderação natural; pois qualquer coisa exagerada foge ao propósito de representar, cujo fim, tanto no princípio como agora, era e é oferecer um espelho à natureza; mostrar à virtude seus próprios traços, ao ridículo sua própria imagem, e à própria idade e ao corpo dos tempos sua forma e aparência (Shakespeare, 1995, p. 94).

Mas, se o passado pode constituir esse pano de fundo para pensar o presente, ele náo cessa de engendrar um perigo: o de uma idealização, de uma tentativa de retorno, ou de um saudosismo inócuo que acredita estar lá, na distância da Antiguidade, a verdade que devemos almejar. Meu interesse pela abordagem de Foucault repousa justamente no fato de ele náo tomar o passado como modelo, mas como problematização.

Para Revel (2004), problematizar - no pensamento foucaultiano - significa interrogar os objetos, as regras de ação ou modos de relação em suas formas historicamente singulares, bem como na forma com que eles representavam - ou representam -, em uma determinada 
época, certo tipo de resposta a determinado tipo de problema. Assim, problematizar implica "[...] instaurar uma distância crítica, fazer atuar o 'afastamento', reconhecer os problemas" (Revel, 2004, p. 82).

Principiemos pela distância crítica. Ora, estou me referindo principalmente à obra A Hermenêutica do Sujeito, e talvez fosse possível creditar parte dessa visão ao conceito basal da reflexão que tento apresentar aqui: o de cuidado de si (souci de soi), de práticas de si, das relaçóes consigo, do ocupar-se consigo.

Em primeiro lugar, trata-se de conceitos que não se equivalem entre si. Mais do que isso, porém, trata-se de discussóes que, embora não tenham ficado restritas aos períodos helenístico e romano, tampouco aos primeiros séculos da era cristá, configuraram-se de tal forma nesses períodos que náo deixam de nos seduzir quando pensamos sobre as experiências de hoje. Isso porque esses conceitos se referem a um tema maior sobre o qual Foucault, então, se debruçava: o da relaçáo entre sujeito e verdade.

O próprio Foucault formula a questão que o instiga da seguinte maneira: "[...] em que forma de história foram tramadas, no ocidente, as relaçóes, que não estão suscitadas pela prática ou pela análise histórica habitual, entre estes dois elementos, o 'sujeito' e a 'verdade"' (Foucault, 2004, p. 4). Os que se debruçaram sobre sua obra - refiro-me principalmente aos autores de Foucault, a coragem de verdade (Gros, 2004) - afirmam que ele levou a cabo, como poucos, em sua própria existência, uma experiência da verdade, uma coragem de verdade, que explodia em seus atos. Ele experimentou uma relação radical entre o trabalho teórico e a prática de vida, de forma "[...] a fazer da própria existência o teatro provocador do escândalo da verdade" (Gros, 2004, p. 163).

Foi nessas condiçôes que Foucault interessou-se pela implicação recíproca entre um estilo de vida e certo modo de perscrutar a si mesmo, por uma correspondência possível e necessária entre o dizer e o fazer. Essa dupla implicação foi justamente o que me fez pensar sobre as práticas teatrais, os modos de elaborá-las numa formação em teatro, como um possível modo contemporâneo de se perscrutar. Com efeito,

[...] não se trata de regular a própria vida segundo um discurso e de ter, por exemplo, um comportamento justo defendendo a própria ideia de justiça, mas de tornar diretamente legível no corpo a presença explosiva e selvagem de uma verdade nua [...] (Gros, 2004, p. 163). 
Do que se trata esta verdade inscrita no corpo, por assim dizer, tatuada por força das açóes? Verdade nua que explode como presença legível num corpo que age? Verdade habitada por uma lógica especial, por uma realidade transfigurada, pela própria ficção, quiçá, parafraseando Shakespeare, uma verdade feita da matéria de que são feitos os sonhos?

Retorno ao pensamento de Foucault para deter-me no modo como esse autor traça sua ideia de verdade e a respectiva relaçáo desta com a constituição de subjetividade. A noçáo de cuidado de si, tal como pensada por Foucault a partir dos textos da Antiguidade, faz ver como aqueles pensadores não dissociavam o acesso à verdade das transformaçóes necessárias no próprio ser do sujeito que se abria a esse acesso. É justamente tal junção entre filosofia e espiritualidade (como forma de pensamento e de prática), entre verdade e o modo de praticá-la, que está na noção de cuidado de si. Salma Tannus Muchail (2004) sintetiza essa questão ao dizer que

[...] o cuidado de si, assim entendido, remete não somente ao plano da intelecçáo ou do conhecimento - embora o inclua -, não apenas ao âmbito das teorias - embora as justifique -, não somente à ordem da representação - embora a fundamente -, mas também ao plano das atitudes, ao âmbito do olhar, à ordem das práticas, que constituem todo um modo de existência (Muchail, 2004, p. 9).

A noção de cuidado de si parece configurar, assim, um modo complexo e radical de constituiçáo dos sujeitos, que abarca náo somente a capacidade de perceber e pensar os atos, mas sobretudo um modo de edificá-los. É sob a égide dessa coerência entre pensamento e prática que Foucault se detém sobre outra noçáo constituinte da ascese grega antiga: a parrhesia, o tudo dizer, o franco falar, a liberdade e a abertura que tornam possível que se diga o que se tem a dizer, da maneira que se escolheu e no tempo exato que se tem vontade de dizer, segundo a forma que se crê ser necessário dizer (Foucault, 2004). $\mathrm{O}$ termo parrhesia está diretamente relacionado não só à escolha, à decisão, à atitude de quem fala, mas também a um modo de ação historicamente singular, que assumiu formas e funçóes particulares no tempo/espaço em que foi vivenciada.

Conforme Gros (2004), Foucault intitulou seu último curso no Collège de France, no qual se debruçou sobre o tema da parrhesia, de $A$ coragem da verdade (2004), e constituiu, a partir desse nó da coragem e da verdade, algo como "um complexo fundamental" 
(2004, p. 11), uma chave que permite ler e olhar para a obra e para a vida como indissociáveis entre si. A coragem da verdade une a escrita e a ação como uma única e mesma coisa. Assim, náo é possível ter, de um lado, um discurso de verdades e, de outro, uma coragem que busca causas a defender. Afinal, "[...] há algo de mais essencial que qualquer verdade: a exigência da verdade" (Gros, 2004, p. 12).

$\mathrm{Na}$ experiência dos gregos dos séculos I-II da nossa era, ascetismo e acesso à verdade estavam implicados mutuamente. Para eles, só era possível tornar-se sujeito de uma verdade na medida em que o sujeito se transformasse, em contato com a própria verdade. $\mathrm{Na}$ concepçáo grega de parrhesia, a aquisição de certas qualidades morais era o que garantia a posse da verdade, pois o fato de possuir essas qualidades representava a prova de que se tem acesso à verdade e vice-versa (Foucault, 2004).

A confiança que se podia ter na veracidade das palavras de um parrhesiasta derivava do fato de que o cidadáo mostrava, por seus atos, que náo se limitava a crer: ele aplicava essa verdade à própria existência. Por isso mesmo, "[...] náo pode haver ensinamento da verdade sem que aquele que diz a verdade dê o exemplo desta verdade [...]" (Foucault, 2004, p. 492). Ou ainda, “[...] está presente em uma coincidência entre o sujeito da enunciação e o sujeito de seus próprios atos" (Foucault, 2004, p. 495). Assim, um critério que permite julgar a verdade de um discurso é a coincidência entre dizer e fazer.

No exemplo de vida de Foucault, os temas e conceitos sobre os quais ele se dedicou agem nas próprias escrita e fala do filósofo. Esses temas e conceitos constituem e impregnam tudo o que ele registrou e expôs de si mesmo. Trata-se de uma conversão especial do olhar sobre si mesmo que se estende sobre o mundo e sobre os outros. Isso produz a dimensão espiritual do sujeito e do ato de verdade.

Com efeito, a parrhesia estabelece como questão principal a separação entre o verdadeiro e o falso. Essa separação se dá a ver na fala de alguém (o mestre, por exemplo), cujos atos atestam a veracidade da fala - diferentemente da retórica, outro modo de expressáo que se concentra no modo de falar, e não tanto na verdade do que é dito. A parrhesia supóe, assim, uma fala engajada, uma adesão do falante à própria enunciação, um modo de enunciar a verdade que constitui uma convicção pessoal, ao passo que o problema da retórica não está em acreditar no que se diz, mas em fazer o outro (aquele que escuta) crer. A convicçáo torna-se menos importante que a persuasăo. No 
caso da parrhesia, trata-se de uma fala perigosa, pois supóe coragem e implica sempre uma verdade que pode ferir o outro e pela qual se assume o risco de uma reação negativa, ao passo que a retórica busca bajular o outro (Gros, 2004).

Para Foucault (2004), um parrhesiasta corre risco ao dizer a verdade, mas prefere correr esse risco a descansar na segurança de uma vida em que a verdade permanece silenciada. Prefere dizer a verdade a ser falso consigo mesmo.

Ainda que dizer a verdade e correr riscos sejam importantes para constituir a parrhesia, não são suficientes per se, pois a parrhesia é um jogo entre quem diz a verdade e o interlocutor. Um jogo no qual, por exemplo, é possível advertir o outro de que deveria comportar-se de certo modo ou de que está equivocado na forma como pensa ou como age. Um jogo que pode acontecer, também, por meio de uma confissão a alguém com poder sobre aquele que fala, e, portanto, pode censurá-lo ou castigá-lo pelo dito. Assim, a função da parrhesia não é aquela de uma demonstração da verdade, mas sim a de fazer a crítica do interlocutor ou do próprio falante.

Por tudo isso, na parrhesia, dizer a verdade é considerado um dever que, por sua vez, está diretamente relacionado à liberdade que o parrhesiasta tem de exercer. Em suma, a parrhesia é uma atividade verbal em que o falante expressa sua relação pessoal com a verdade e arrisca a própria vida, porque reconhece o ato de dizer a verdade como um dever para melhorar e ajudar os outros e também a si mesmo (Foucault, 2000). Ademais, há uma vinculaçáo inseparável entre dizer, ser e fazer, que póe em evidência a articulação dos dois conceitos foucaultianos: cuidado de si e parrhesia.

\section{À Guisa de Conclusão}

Foi assim, adentrando esses dois universos de discussão a respeito do conceito de verdade - a saber, o de Marcel Detienne e o de Michel Foucault - que foi me ocorrendo uma série de questóes sobre a temática da formação do ator na sua relação com a criação teatral, com a criaçáo de si e com modos de experimentar a verdade. Seria possível pensar o processo de edificaçáo de si - de um artista ator na busca por um corpo fictício que, ao mesmo tempo, lhe possibilita a performance cênica e transforma o seu corpo cotidiano - como uma espécie de relação com uma verdade? Seria esse um modo con- 
temporâneo de praticar uma verdade, unindo discurso e prática de forma indissociada, visto que só é possível pensar em ficção teatral se houver mudança no modo de operar com as açóes corporais e, ao mesmo tempo, se essa mudança for introjetada de tal forma a habitar o corpo e a lógica de criação do artista cênico?

$\mathrm{Na}$ esteira de tudo isso, há a busca pela verdade cênica, que se refere à sinceridade, ao envolvimento, à disponibilidade, à atenção, ao engajamento com que o ator elabora o seu jogo cênico, de forma a torná-lo crível para si mesmo e para os outros da cena (colegas e público). Trata-se da verdade cênica que está diretamente relacionada não só à forma narrativa poética que constitui a prática teatral, mas também ao acontecimento teatral, naquilo que ele preserva de celebração proveniente da sua gênese ritual.

Ao que tudo indica, é justamente nessa rede de imbricamentos - na qual os procedimentos artísticos tornam possível a obra, na mesma medida em que forjam, também, o homem (artista) - que se configura a possibilidade de transformaçáo, de invenção de si. Ao fim e ao cabo, trata-se de uma transformaçáo que tem o corpo como lugar de acontecimento, referência, e que, ao mesmo tempo, ultrapassa a esfera corporal, à medida que não se restringe à ação de um individuo voltado para si, mas de um sujeito artista atuando no seu tempo a partir de uma relação consigo mesmo, no entanto, sempre atravessada pela presença dos vários outros que o constituem. 


\section{Notas}

${ }^{1}$ Constantin Stanislavski (1863-1938), ator e encenador russo, foi fundador do Teatro de Arte de Moscou, em 1898, e seus princípios inscrevem-se na corrente naturalista. Sua contribuição fundamental dentro do quadro realista foi a de redefinir a noção de realismo, colocando a tônica sobre o realismo interior, e de se ligar ao problema da formaçáo do ator. Como o ator pode produzir o verdadeiro, o vivido, numa situação de teatro que é, por princípio, artificial? A resposta de Stanislavski apoia-se num conjunto de técnicas interiores e exteriores, constitutivas de uma psicofísica do ator, que se costuma chamar de Sistema Stanislavskiano (Borie; De Rougemont; Scherer, 2004).

${ }^{2}$ Compreendo que representar alude a um conceito importante e complexo, com várias formulações em diferentes campos. Nesse caso, o verbo está sendo empregado dentro do uso corrente que se faz no campo teatral e que refere a ação do ator euro-americano quanto à sua relação com a criação e os modos de apresentá-la, ou melhor, de reapresentá-la.

${ }^{3}$ Artigo publicado nos Cadernos de Teatro a partir de uma palestra proferida pela atriz Fernanda Montenegro, no Centro de Artes Livres, em março de 1983.

${ }^{4}$ Entendo que as práticas teatrais dizem respeito aos diferentes modos de fazer/praticar e pensar a linguagem teatral, concernente a tempos, espaços, condiçóes sociais específicas. Já as técnicas relacionam-se aos procedimentos que constituem modos específicos de praticar a criação teatral, por exemplo: a técnica do trabalho com o clown, as técnicas de improvisação etc. Por fim, os exercícios constituem a minúcia do trabalho, os elementos que compóem as técnicas, que revelam as práticas.

${ }^{5}$ O termo campo de forças provém das discussões de Kastrup (1999). Segundo a autora, amparada no pensamento de Gilles Deleuze, a figura de um campo de forças de vetores é a figura de um espaço no qual a subjetividade pode emergir, destituída da figura de um sujeito.

${ }^{6}$ Na peça Hamlet, o principe da Dinamarca, de Shakespeare (1995), o personagem (Hamlet) contrata uma companhia de atores para representar um texto escrito por ele. Diante do modo como o ator interpreta o texto, Hamlet o interrompe e o aconselha.

\section{Referências}

ARTAUD, Antonin. O Teatro e seu Duplo. São Paulo: Max Limonad, 1987.

BARBA, Eugenio; SAVARESE, Nicola. A Arte Secreta do Ator. São Paulo/Campinas: Hucitec/Unicamp, 1995.

BERTHOLD, Margot. História Mundial do Teatro. São Paulo: Perspectiva, 2004.

BURNIER, Luís Otávio. A Arte de Ator. Campinas: Unicamp, 2001.

CARLSON, Marvin. Teorias do Teatro: estudo histórico-crítico, dos gregos à atualidade. São Paulo: UNESP, 1997.

CHAUÍ, Marilena. Experiência do Pensamento. Ensaio sobre a obra de Merleau-Ponty. São Paulo: Martins Fontes, 2002. 
COUTINHO, Eduardo. Pré-estreia de Documentário de Eduardo Coutinho na Esdi - Escola Superior de Desenho Industrial, Rio de Janeiro, Universidade do Estado do Rio de Janeiro, 05-11 out. 2007. Disponível em: <http:/www.esdi.uerj.br/noticias/etc/ jogodecena.html>. Acesso em: jan. 2012.

FERRACINI, Renato (Org.). Corpos em Fuga, Corpos em Artes. São Paulo: Hucitec, 2006.

FOUCAULT, Michel. Arte, Epistemologia, Filosofia e História da Medicina. (Ditos e escritos VII). Rio de Janeiro: Forense Universitária, 2011.

FOUCAULT, Michel. Arqueologia das Ciências e História dos Sistemas de Pensamento. (Ditos e escritos II). Rio de Janeiro: Forense Universitária, 2008.

FOUCAULT, Michel. A Hermenêutica do Sujeito. São Paulo: Martins Fontes, 2004.

FOUCAULT, Michel. Resumos dos Cursos do Collège de France (1970-1982). Rio de Janeiro: Jorge Zahar, 1997.

FOUCAULT, Michel. O Pensamento do Exterior. São Paulo: Principio, 1990.

FOUCAULT, Michel. História da Sexualidade 3: o cuidado de si. Rio de Janeiro: Graal, 1985.

FLASZEN, Ludwik; POLLASTRELLI, Carla. O Teatro Laboratório de Jerzy Grotowski 1959-1969. Textos e materiais de Jerzy Grotowski e Ludwik Flaszen com um escrito de Eugenio Barba. São Paulo: Perspectiva, 2007.

GROS, Frédéric (Org.). Foucault: a coragem da verdade. São Paulo: Parábola, 2004.

GROTOWSKI, Jerzy. Em Busca de um Teatro Pobre. Rio de Janeiro: Civilização Brasileira, 1987.

HERMANN, Nadja. Auto Criação e Horizonte Comum. Ensaios sobre educação éticoestética. Ijuí: Unijuí, 2010.

ICLE, Gilberto. Pedagogia Teatral como Cuidado de Si. São Paulo: Hucitec, 2010.

KASTRUP, Virginia. A Invenção de si e do Mundo. Uma introdução do tempo e do coletivo no estudo da cogniçáo. Sáo Paulo: Papirus, 1999.

MONTENEGRO, Fernanda. O ator e seu ofício. Cadernos de Teatro - O Tablado, Rio de Janeiro, v. 97, p. 1-4, 1983.

MUCHAIL, Salma Tannus. Cuidado de si e coragem da verdade (Prefácio). In: GROS, Frédéric (Org.). Foucault: a coragem da verdade. Tradução: Marcos Marcionilo. São Paulo: Parábola, 2004.

PASSERON, René. Da Estética à Poiética. Porto Arte - Revista do Mestrado em Artes Visuais, Porto Alegre, Universidade Federal do Rio Grande do Sul, v. 8, n. 15, p. 103-116, nov. 1997.

SHAKESPEARE, William. Hamlet e Macbeth. Rio de Janeiro: Nova Fronteira, 1995.

STANISLAVSKI, Constantin. El Trabajo del Actor sobre si Mismo en el Proceso Creador de la Vivencia. Barcelona: Alba, 2007. 
STANISLAVSKI, Constantin. El Arte Escénico. Madrid: Siglo XXI de España Editores, 1999.

STANISLAVSKI, Constantin. Manual del Actor. México: Editorial Diana, 2001.

Celina Nunes de Alcântara é graduada em Artes Cênicas pela Universidade Federal do Rio Grande do Sul (1991), mestre (2004) e doutora (2013) em Educação pela Universidade Federal do Rio Grande do Sul. É professora adjunta na mesma instituição, no Departamento de Arte Dramática. É atriz integrante da UTA-Usina do Trabalho do Ator (www.utateatro.com.br), grupo de criação e investigação teatral e pertencente ao GETEPE-Grupo de Estudos em Educaçáo, Teatro e Performance. E-mail: celinanalcantara@gmail.com

Recebido em 27 de janeiro de 2013 Aprovado em 22 de maio de 2013 